\title{
Exploring subtle land use and land cover changes: a framework for future landscape studies
}

\author{
Thomas Houet • Thomas R. Loveland • Laurence Hubert-Moy • Cédric Gaucherel • Darrell Napton• \\ Christopher A. Barnes • Kristi Sayler
}

5

T. Houet (corresponding author)

GEODE - UMR CNRS 5602,

Université Toulouse 2, 5 allée Antonio Machado, 31058 Toulouse Cedex 9, France

e-mail : thomas.houet@univ-tlse2.fr , Phone : +33 (0)5 61503628 / Fax : +33 (0)5 61504275

10

T. R. Loveland and K. L. Sayler

U.S. Geological Survey Earth Resources Observation and Science (EROS) Center 47914 252nd Street, Sioux Falls, SD 57198-0001 USA

15

L. Hubert-Moy

COSTEL - UMR CNRS 6554 LETG / IFR 190 CAREN,

Université Rennes 2, Place du recteur Henri Le Moal, 35043 Rennes cedex, France

C. Gaucherel

20 INRA - EFPA, UMR AMAP, 34398 Montpellier Cedex 5, France

\section{Napton}

Department of Geography, South Dakota State University, Brookings, SD 57007 USGS

C. A. Barnes

SGT, Inc. USGS EROS Center

47914 252nd Street, Sioux Falls, SD 57198-0001 USA

Version: 21/01/2011

30 Manuscript word count (including abstract, text, references, and captions): 8826 words Manuscript word count (abstract and text only): 6590 words 


\begin{abstract}
Land cover and land use changes can have a wide variety of ecological effects, including significant impacts on soils and water quality. In rural areas, even subtle changes in farming practices can affect landscape features and functions, and consequently the environment. Fine-scale analyses have to be performed to better understand the land cover change processes. At the same time, models of land cover change have to be developed in order to anticipate where changes are more likely to occur next. Such predictive information is essential to propose and implement sustainable and efficient environmental policies. Future landscape studies can provide a framework to forecast how land use and land cover changes is likely to react differently to subtle changes.

This paper proposes a four step framework to forecast landscape futures at fine scales by coupling scenarios and landscape modelling approaches. This methodology has been tested on two contrasting agricultural landscapes located in the United States and France, to identify possible landscape changes based on forecasting and backcasting agriculture intensification scenarios. Both examples demonstrate that relatively subtle land cover and land use changes can have a large impact on future landscapes. Results highlight how such subtle changes have to be considered in term of quantity, location, and frequency of land use and land cover to appropriately assess environmental impacts on water pollution (France) and soil erosion (US). The results highlight opportunities for improvements in landscape modelling.
\end{abstract}

Key words: scenarios, modelling, forecasting, backcasting, LULCC, agriculture, Brittany, CornBelt, prospective

\title{
55 1. Introduction \& background
}

\subsection{Subtle land use and land cover changes in agricultural areas}

Humans dominate most of the earth's ecosystems, often with dramatic impacts on global biodiversity and biogeochemical cycles (Vitousek et al. 1997). For example, land use and land cover changes over the past 50-100 years contributed to significant changes on local-to-global 
60 climate conditions, loss of biotic diversity and ecosystem health and functioning (Houghton et al. 1999; Sala et al. 2000; Matson et al. 1997). The impact of agriculture is unparalleled in its combination of spatial extent and intensity of influence (Lambin et al. 2001). Agricultural intensification has induced dramatic consequences on habitats, water degradation, and biodiversity (Maron and Fitzsimons 2007; Butler et al. 2007; Gordon et al. 2008).

In rural areas, even subtle changes in farming practices can affect landscape features and functions and consequently the environment. Agriculture has impacts at fine scales where landscape structure, including the mosaics of hedgerows and fields, affect local hydro-geochemical processes and species composition (Medley et al. 1995). Moreover, local alteration of land use and land cover can have global consequences that require local and regional solutions and the cooperation of the world's policy_makers, land managers, and other stakeholders in land management at local, regional and global scales (Encyclopaedia of Earth 2007). Furthermore, agricultural landscape patterns are driven by multi-scale driving forces - from the global economy, international policies, and regional soils’ properties. to local social choices and practices (Veldkamp et al. 2001). Most land use and land cover changes (LULCC) occur at the farm scale where these driving forces are integrated (Kristensen et al. 2001; Baudry and Thenail 2004). However, subtle LULC changes are often disregarded for at least two reasons. Their detection from remotely sensed data is uneasy or impossible (limited spatial extent, hidden by another land cover, etc.). Their changes are quantitatively not significant so their impacts are often underestimated and neglected. They are defined as land cover and land use modifications that affect the character of the land cover without changing its overall classification and mostly rely to local LULCC processes (Lambin and Geist, 2008). Few LULCC studies are carried out at fine scales such as the farm scale, whereas most of them are conducted at landscape or regional scales using pixels of various sizes as units of observations. Fine-scale analyses, however, have to be performed to better understand the land cover change processes (GLP 2005), and models of land cover change have to be applied and refined in order to anticipate where changes are more likely to occur next. Such predictive 
information is essential to propose and implement local sustainable environmental policies and efficient in situ actions.

\subsection{Aims of Future Landscape Studies (FLS)}

Most international research programs, e.g. International Geosphere-Biosphere Programme - IGBP

(Lambin et al. 1999) and the Millennium Ecosystem Assessment (MEA 2003) focus upon

monitoring LULCC and providing knowledge to help achieve sustainable environments. Exploring the future is one way to achieve this goal. Decision makers can better adapt to uncertain conditions, if they have tools to explore alternative futures (Godet 1986). Future studies can change the world by changing our vision of what we would like for it to be. Future Landscape Studies (FLS) use studies and approaches that draw on coupled approaches to integrate various techniques and tools including landscape and LULCC models, participatory analyses, and scenarios (Marien 2002; Kok et al. 2007). FLS considered here include all LULCC and landscape studies that aim to project future states of the land. The notion of landscape has been highly recognized as an integrated framework for many conservation and land resource issues that involve the interaction of local ecological and land use processes, global changes, socioeconomic effects, demographic changes and policies (Franklin 1993). Hobbs (1997) and Nassauer and Corry (2004) stressed the relevance of this integrated organization level to explore futures of landscapes to better understand landscape structure, functions and changes, and to assess the impacts of possible landscape dynamics on environmental resources at local, regional and global scales (Kok et al. 2007). Most existing FLS’s

105 produce possible future states from regional, national, or global scales (Veldkamp and Fresco 1997; de Nijs et al. 2004; Verburg et al. 2008) through pixel-based mapping at more or less coarse resolution (e.g. from $500 \mathrm{~m}^{2}$ to $1 \mathrm{~km}^{2}$ ). At such coarse resolutions, these future states can contribute to assessments of the consequences of LULCC on climate (IPCC 2000) and carbon sequestration (Schulp et al. 2008), and they focus on policy issues such as those useful for decision makers to

110 define agricultural and environmental policies at the regional or global scale. We make the assumption that FLS can also provide a framework to forecast land use and land cover changes in 
response to subtle changes. Indeed, we think that to better assess environmental impacts of future landscape changes, FLS should also take place at the landscape feature scale. Fine scale FLS are able to render possible future states for landscape features such as hedgerows, fields, and local corridors that are needed for environmental assessments. The few existing fine scale FLS are presented through forms such as drawings, photo-realism (Nassauer and Corry 2004), virtual representation of part of the landscape (Tress and Tress 2003; Sheppard 2005) or maps (Munier et al. 2004). If fine-scale outputs are to effectively communicate landscape changes to better involve local actors and policy makers in environmental management (Bousquet and Le Page 2004), then another challenge is to merge both realistic portrayals and quantitative assessments of the impacts of future changes for small management units.

\subsection{Coupling landscape model and scenario based approaches to forecast subtle LULCC}

Scenario-based landscape modelling approaches are commonly used to produce FLS. Scenario development is a relatively new and under-explored method in land use change research (Kok et al. 2007). Integrated approaches in which models and scenarios are developed in close interaction with stakeholders still remain a challenge. This study is part of this effort to improve coupling between landscape models and scenarios for fine scale FLS.

From a 'landscape modelling point of view’, FLS are strongly dominated by dynamic models. In this study, however, landscape models are considered using a wider definition that includes spatially explicit models, such as synchronic landscape representation techniques that use multicriteria and GIS methods (Paegelow and Olmedo 2005), virtual landscape modelling (Sheppard 2005), and dynamic models (Agarwal et al. 2002; Verburg et al. 2004). Synchronic techniques are used to model possible future states whereas dynamics models aim at simulating spatial properties of possible future achievements and states. From this point of view, two dynamic

135 landscape modelling approaches can be distinguished: 'bottom-up, anthropologic, process-oriented' versus ‘top-down, land evaluation, pattern-oriented’ approaches (Geoghegan et al. 1998; Castella et al. 2007). The first often refers to agent-based models (Parker et al. 2003) or (pseudo) object- 
oriented models (Maxwell and Costanza 1997) that model micro-level land use changes and land users behaviour (Munier et al. 2004; Bousquet and Le Page 2004). The second approach is 140 prevalent in LULCC modelling and is supported by grid-based studies. This approach is not really appropriate for fine scale LULCC modelling (Houet and Hubert-Moy 2006) and downscaling LULCC modelling is still a challenge (Verburg et al. 2006a).

In the Futures field research, the use of scenarios is common. There are a number of scenarios typologies and several good overviews of the wide variety of techniques existing to build scenarios

145 (Greeuw et al. 2000; van Notten et al. 2003; Borjeson et al. 2006). Scenarios are defined as hypothetical sequences of events constructed from mental maps or models for the purpose of focussing attention on causal processes and decision points (Kahn and Wiener 1967). From a 'scenario's point of view', FLS can be classified according to a broad methodological typology as either forecasting or backcasting scenario-based studies. According to the commonly accepted 150 definitions, forecasting (or explorative) scenarios always look to the future based on forward induction and answer the question what might happen? Backcasting (or normative) scenarios are proactive, based on wildcard trends that break assumptions, and backward induction from the future to the present to answer the question how can a specific situation be reached? (Godet 1986; Bain and Roubelat 1994; Godet and Roubelat 1996). According to Greeuw et al. (2000) and Borjeson et 155 al. (2006), forecasting scenarios in FLS are often quantitative, dynamic, model-based studies, whereas backcasting scenarios are mostly based on qualitative, narrative, and synchronic landscape modelling approaches. Scenarios implicitly influence the use of synchronic or dynamic landscape models in FLS. Explorative FLS based on dynamic models are over-represented in the literature compared to normative FLS. This imbalance is unfavourable for FLS considering the advantages 160 and complementarities of both type of scenarios (Godet and Roubelat 1996); forecasting scenarios are relevant to emphasize trends of future uncertainties by exploring a range of driving forces based on trends or predefined management strategies; backcasting scenarios seek explanation or emergence of strategies to reach desirable or avoid unbearable situations. 


\subsection{A generic scenario-based fine scale FLS framework?}

165 The aim of this paper is to propose a generic framework to produce fine scale FLS. The proposed methodology is based on 'la prospective' approach (Godet 1986). Rather than view the future as a continuation of the past, in this approach future states are based on the wishes of various actors and the constraints imposed on them by the economic and social forces and the environment. To test its generic potential, we applied 'la prospective' approach to two contrasting study sites that represent agricultural landscapes in different cultural settings. These examples of fine scale FLS based demonstrate both forecasting (US study site) and normative (French study site) agricultural intensification scenarios. In these sites, most of the land is cultivated and intensification results in an increased use of fertilizers combined with spatial extension and increased proportions of crops at the expense of grassland. This FLS framework aims to be independent of a specific scenario or

175 landscape model approach. Most of FLS are driven by LUCC model capability so that explorative scenario-based studies are predominating in detriment of normative scenario-based studies and combined approaches. Moreover, FLS are often based on scenarios made previously and separately and then mapped using existing models. We claim that a more integrative work based on futurologists and landscape modellers’ practices would be more suitable to face models limitations and future uncertainties. This paper aims at providing a generic conceptual framework according to futurologists' methods to landscape modellers, landscape ecologists and landscape planners to better integrate LULCC processes in futures exploration. To illustrate our purpose, we use two different scenario building and landscape modeling approaches on two contrasted study sites; forecasting scenarios are developed using the L1 dynamic landscape platform (Gaucherel et al. 2006) in the US site, and normative scenarios are narrative coupled with multi-criteria GIS based maps in the French site. The results quantify possible future landscape changes and their uncertainty, and also their possible impacts on soil erosion and water quality. Finally, we discuss (i) the relevance of fine scale FLS framework to better understand subtle landscape changes in environmental assessments and (ii) opportunities for future improvements for fine scale FLS. 


\section{Fine scale FLS framework}

The proposed framework is based on la prospective approach, which is a way of thinking based on action and non-predetermination using specific methods such as scenarios. Its aim is not to predict the future but to transform exploratory and normative anticipation into action (Bain and Roubelat 1994). Prospective scenarios are designed from a meta-method (Godet 1986) defined in three steps:

(i) system analysis to answer the question "How is the system evolving, how has it evolved, and how is it functioning?", (ii) definition of scenarios that establish assumptions for the future considering trends and actors' strategies, and (iii) scenarios assessment in which future changes and knowledge brought by scenarios are evaluated.

Based on the assumption that landscape ecology is an appropriate interdisciplinary approach to produce FLS (Hobbs 1997, Santelmann et al. 2004), we adapted this scenarios’ method in order to integrate landscape study techniques into their production. The proposed framework comprises four steps (Fig. 1). The first step involves selecting study site(s) with appropriate landscape representativeness. Step 2 concerns the analysis of the studied landscape as a system, including the identification of past, present, and future landscape trends, lands uses and driving forces. Detection of past landscape changes and land uses is commonly done using remotely sensed data and fieldwork. The identification of past and contemporary driving forces and land use practices influencing landscape changes (Burgi et al. 2004) is done using spatial analysis, which is often coupled with statistical and participatory approaches (Bousquet and Le Page 2004; Overmars et al. 2007). Driving forces are defined as human activities and processes that cause land cover and landscape feature changes and which influence trajectories of landscapes. Driving forces influence land uses. Land uses are defined as land management practices related to production and maintenance (e.g. crops successions) that directly affect landscape changes. Future driving forces and causes of landscape changes are defined by considering trends, actors' strategies, and environmental stakes. Step 3 consists of mapping scenarios. According to the identified stakes, including testing trends of land uses and decision maker involvement, the appropriate type of 
scenario may vary. To be able to implement both forecasting and backcasting, scenarios must be defined before choosing an appropriate landscape modelling approach. Step 4 consists of monitoring landscape changes, which includes assessing environmental impacts and knowledge for decision makers.

\#Figure 1 approximately here\#

\section{Materials and methods}

\subsection{Study sites}

We built scenarios for two contrasting US and French study sites that experience agriculture intensification. The two sites are different in size $\left(127 \mathrm{~km}^{2} v s .13 \mathrm{~km}^{2}\right)$, agriculture production (cash grain crops vs. dairy productions), landscape (open field vs. bocage landscapes), and environmental issues (soil erosion vs. water pollution). The US study site is one of the three thousand random sample sites used in the U.S. Geological Survey (USGS) Land Cover Trends research project (Loveland et al. 2002). The 'Menno block' (Fig. 2a) is entirely contained within Hutchinson County, southeastern South Dakota, in the Northern Glaciated Plains Ecoregion (Omernik 1987). Cash crops production (corn and soybeans) is dominant, and livestock production is also important. The Menno block is a 10x10 km sample square; however the studied area is slightly larger (127 $\mathrm{km}^{2}$ ) so that entire fields could be included in the study. In 2001, the dominant land cover classes were corn (32\% of the whole area) and soybeans (28.5\%). Hay (10\%) and alfalfa (8.3\%) are used for livestock production and to improve soil fertility. Natural grasslands are often used to pasture cattle. The French study site is located in the western part of France (Fig. 2b). The landscape of the Lestolet watershed has a dense hedgerow network with relatively small fields (1.4 ha mean size field in 1998). Dairy farms are the major type of agriculture. In 1998, the landscape was characterized by temporary grassland (44\%), corn (17\%), wheat (15\%), fallow lands (13\%), woodlands (5\%), permanent grasslands (3\%), a dense hedgerow network (123 m/ha), and large 240 riparian wetlands (220 ha).

\#Figure 2 approximately here\# 


\subsection{Description and analysis of land use changes}

Landscape trends were determined using aerial photographs and satellite images summarized in appendix 1. The Menno site experienced agricultural land use intensification after 1973. This was characterized by the conversion of natural grassland to cropland (+3.5\% in $1973-84$; $+2 \%$ in $1992-$ 2000). Additionally, small fields of natural grassland located in valley bottoms had changed to woodlands. Lestolet trends have been detailed in Houet and Gaucherel (2007) and show significant conversion of temporary grassland to cropland over the last 20 years $(+5 \%)$, a large reduction of bocage density (-100m/ha), a slight decrease of riparian wetlands surface (-4\%) in which severe

250 grassland to fallow and wood land changes occurred (called hereafter 'riparian landscape enclosure') and field size enlargement over the last 50 years.

\#Appendix 1 approximately here\#

Driving forces were determined and ranked using several techniques: meeting with local actors (farmers, U.S. and French agricultural agents), interviews with experts, systematic analysis, and

255 quantitative statistical and spatial analysis. Most of LULCC were derived and characterized in terms of conditions, direction, location, and quantity from land cover maps and GIS data (e.g. soil properties, farm land use), and participatory meetings.

\subsection{Scenarios assumptions and building approaches}

We developed three ‘agriculture intensification’ scenarios; two forecasting (Menno) and one 260 backcasting (Lestolet) scenario (Table 1).

US scenarios are part of an USGS research initiative and thus were defined by USGS scientists in collaboration with local agents. The US Northern Glaciated Plains ecoregion is affected by significant soil erosion. We defined scenarios to foresee what could be the consequences of agriculture intensification in Menno from 2000 to 2020. Two scenarios were made: a "business as 265 usual” scenario (Sc1) based on the assumption that current practices and Corn Belt specialization continues; the second scenario (Sc2) is a higher intensity variation of Sc1. It is based on Sc1 but integrates no renewal of the federal Conservation Reserve Program (CRP), which consists of a 10 
year contract to convert cropland to grassland or tree cover using practices that reduce soil erosion and improve biodiversity (Sullivan et al. 2004). CRP land accounts for $2.5 \%$ of the Menno block (USDA 2002).

Agricultural land use intensification in Brittany over the last 30 years has caused water pollution. The scenario for the Lestolet was developed with decision makers, local stakeholders (farmers, water managers), and scientists to develop more efficient long-term water management. Hedgerow removals in Lestolet resulted in nitrogen concentrations that rose to 35 mg..$^{-1}$ in 2000 (Mérot 1999), 275 riparian wetlands abandonment (Mérot et al. 2006), and changes in agricultural practices. Stakeholders recommended designing contrasted scenarios. Only one of the water quality scenarios is presented here. It aims to (i) facilitate understanding about what an intensively farm landscape that results in highly degraded water would look like in 2030? and (ii) how will this situation be reached? The scenario (Sc3) starts in 2005 and ends in 2030. It is based on plausible future states of 280 landscape features such as hedgerows, riparian wetlands, and agricultural land covers. Hypotheses about future land management are consistent with each other and with agriculture intensification. These include (i) a massive removal of hedges on hill slopes and plateaus and the maintenance of hedges that surround valley bottom wetlands, (ii) an overall riparian wetlands landscape enclosure, and (iii) European policies that favour crop production (i.e. Common Agricultural Policy aid 285 payments for major arable crops). Finally, Sc3 downscales regional, national, and European socioeconomic projections such as regional water management scenarios, regional agricultural demographic trends by 2015, and farm size projections for France by 2020. Sc3 also integrates study site specificities including farm composition, production system, and future landscape assumptions. This scenario shows the strongest agriculture intensification in a set of backcasting 290 and forecasting scenarios made for this study site (Houet and Hubert-Moy, 2008).

Differences between scenarios in terms of agricultural context, type of landscape, size of study site, and environmental issues are essential to test the framework genericity within the scope of 
agricultural intensification. Table 1 summarizes the scenarios’ approaches and techniques used for each study site.

295 \#Table 1 approximately here\#

\subsection{Landscape modelling techniques to map scenarios}

Spatial rendering of US future landscape scenarios is based on a dynamic and spatially explicit modelling platform (L1) that mechanistically simulates landscape dynamics (Gaucherel et al. 2006). This platform was designed around a kernel, which provides a stable organizational data structure

300 (storyboard, time steps...) and a generic landscape description: landscape processes applied on diversified landscape units and gathered in a coherent landscape mosaic. The L1 model works with various scales (land cover, farms, watershed) and intends to simulate the dynamics of elementary units of each scale (hedgerow, field, farm, etc). Units are polygons or lines represented in a raster mode GIS coverage. One of the main unique features of L1 is the allowance of attributive as well as geometrical actions. Attributive modification implies a change of the main unit property (e.g., land cover change), as in LULCC models, while geometrical modifications refer to unit deformations. In this study we only consider attributive modifications. The L1 model is somewhat different from usual agent-based models (ABM), as its 'agents' (the landscape patches) would not communicate between each other. Landscape patches are interacting through neighbouring and multi-level

310 influences without any message exchange. L1's ability to simulate plausible LULCC has been evaluated through several tests of sensitivity and the simulation of LULCC evolution over time (1981-1998) (Houet and Gaucherel 2007).

Simulation of landscape changes is driven by sets of processes reproducing landscape changes that evolve yearly such as crop successions, land conversions, land acquisitions, etc., that may occur at

315 the farm scale. Some of these processes may differ according to farm specificities (system of production, size, etc), land constraints (soil moisture, thickness, slope, etc), and agronomic constraints (compulsory crop successions, age/occurrences of land covers). Initially developed for a patchy French landscape, L1 has been adapted to simulate future LULCC in the Menno study site. 
L1 simulates LULCC based on a 'storyboard' and at a single time-step defined by the user. This storyboard describes (i) which and when processes occur (every year, one specific year empirically and/or randomly chosen year) and (ii) how many times a process occurs within the chosen time step. In this study, the process of crop succession is used every year, the 'CRP fields conversion into cropland' process occurs in 2008 , and mean soybean proportion rises up to $5 \%$ for all systems of production in 2010 according to scenarios 1 and 2 . An assumption is made that all farmers adopt

325 identical practices the same year to provide the most contrasted scenario. Then, L1 first simulates within each farm (Fig. 3c) inevitable crop successions and then randomly chooses stochastic crop successions (Fig. 3a) according to existing land constrains combined in a single physical environment suitability map (Fig. 3b) to reach the expected amount of crop proportions for the corresponding system of production (Table 2). The resulting map of the previous time-step is used as input for the next one. Crop successions and land constrains were identified from 2000-2001 South Dakota crops maps, 2003-2004 digital orthorectified mosaic interpretations, interviews with farmers and USDA agents, and from Berg et al. (2002) and soil survey (USDA 1979, 1978). Agricultural land use data were obtained from farmer interviews. Only two thirds of land users were identified thus reducing the size of the study site $\left(84.2 \mathrm{~km}^{2}\right)$.

\#Table 2 approximately here\#

\#Figure 3 approximately here\#

Spatial rendering of the backcasting scenario (Sc3) is based on a multi-criteria GIS based approach. Expected future changes were quantified for 2030 by mapping retained assumptions, and for 2015, assumptions were based on trends and the expected 2030 situation. Thus, based on the scenario and according to the expected number of farms and their system of production defined by local experts, expected land cover proportions were easy to derive from a GIS. Location of future landscape changes were randomly chosen but verified multi-criteria rules of land uses. Thus, no unique future existed but our experience has shown that no significant differences exist for possible images of the 2030 landscape given the hypotheses retained. Figure 4 summarizes the multi-criteria land uses rule 
set used to quantify and allocate future landscape changes for 2015 and 2030. For example, for dairy based production systems, hedgerows would be removed to reach expected lower hedgerow densities. Removal is more likely when hedgerows are located between two crop fields, and is likely when neighboured by one crop field if that field is located far from the farmstead. Exceptions are when hedgerows separate two farms, are neighbouring permanent grassland and are located beside roads or within riparian wetlands.

\#Figure 4 approximately here\#

\subsection{Assessment of landscape changes and possible environmental impacts}

The objective for the assessment of forecasting scenarios is to localize and quantify future LULCC and measure uncertainty through computation of mean, minimum and maximum land cover proportions after simulation of fifty runs of Sc1 and Sc2. We then correlated these changes with the hazard of soil erosion. Considering corn as a land cover increasing soil erosion potential (Wilson et al. 2008), a simple corn occurrences indicator is computed and compared with plots of high erosive potential (USDA 1978, 1979). The backcasting scenario assessment was done (i) within the storyline through estimations based on literature and approved by experts, and (ii) by combining future landscape maps with water flux simulation models. We illustrated impacts on theoretical hydrograph peak water flows using the Ruicells model (Langlois and Delahaye 2002).

\section{Results}

In this section, we present Sc1 to Sc3, their implications on LULCC, and assessments of environmental impacts related to these scenarios.

\subsection{US land use intensification scenarios: future changes and environmental assessment}

In 2000, cash crop production was mainly dedicated to national market and bio-ethanol production (corn) and to international markets (soybean). Due to Brazilian soybean production penetration on the international market since 2005, US soybean production has become less attractive. In 2006, the international energy situation has prompted the US government to adopt new energy policies and to enhance biofuel production. Soybeans are particularly adapted to bio-diesel production allowing 
farmers to preserve their soybean production until 2012 and even increase it after 2012. The main uncertainty exists surrounding the CRP. Sc1 assumes that farmers would keep lands enrolled in the CRP in grassland after the 1998-2008 program has ended. Because of the CRP, natural grassland proportion is stable and conversion to cropland has stopped. Indeed, social (hunting areas) and natural (biodiversity preservation) interests were predominant in farmers' choices to maintain grasslands. Inversely in Sc2, most Midwest and Great Plains grasslands in the CRP will be affected by expected reductions of acres eligible for CRP participation. Priority eligibility will be for filter strips along perennial streams, urban watersheds, and areas with habitat needed by threatened species. In Sc2, Menno CRP fields are converted to cropland in 2008. Land use intensification results from technical advances: in 2010 crop successions stop depending on soil fertility, which allows farmers to increase their soybean proportion (up to 5\%) to balance corn and soybean production.

Results of Sc1 and Sc2 are presented in figure 5 and table 3 and respective simulations are available online (Appendix 2 and 3). They are analyzed over 6-7 year time periods and not from year to year in order to differentiate LULCC resulting from crop successions from those resulting from land use intensification. Between 2000 and 2006, mean crop proportions are similar for both scenarios. From 2006 to 2020, the trend of land use intensification generates (Sc1) a mean increase of $+2.9 \%$ corn (+244 ha) and $+3.2 \%$ soybeans (+270 ha), mainly at the expense of hayfields (Tab. 3). Coupled with the end of the CRP in 2008 inducing 232 ha of natural grasslands converted to cropland (2.5\% of the study site), land use intensification (Sc2) shows similar tendencies but proportions slightly differ: $+3.4 \%$ corn and $+4.7 \%$ soybeans (Tab.3). Computation of uncertainties (Fig 5 ) proves that trends of land cover changes for each scenario are distinguishable and not resulting from stochastic simulations.

\#Table 3 approximately here\# 
Sc1 shows a significant average amount of corn occurrences (corn every 2.1 years, Fig. 6a). Figure 6b exhibits differences of mean values of corn occurrences between Sc1 and Sc2. White fields show no significant differences ( $< \pm 1$ occurrence). Small differences $(< \pm 2$ occurrences) result from stochastic crop successions. High differences ( $> \pm 2$ occurrences) result from land use intensification. High positive values ( $>4$ ) concern farm fields where 'CRP to cropland' conversion occurred. Decreasing of corn occurrences is induced by cropland expansion engendering more possibilities for corn establishment. Yet, if directions of change (gain or loss of corn occurrences) are quantitatively nearly similar (respectively 801 ha and 760 ha), change intensity varies (Fig. 6c). High positive changes correspond to fewer CRP fields converted to cropland in 2008, which is

405 balanced by slight decreasing corn occurrences on agricultural fields. Compared to fields exhibiting high erosion hazards (grey strip cross fields - Fig. 6b), land use intensification does not sensibly affect these fields.

\#Figure 6 approximately here\#

\subsection{French land use intensification scenario: future changes and environmental assessment}

410 The new European Union (EU) CAP reform took place in November 2005. Farmers adapted to the amount of EU financial aid they will receive annually until 2013-2014. New CAP and international market strategies favour maintaining or increasing wheat proportions. In 2006, Lestolet was not recognized as a priority watershed by water managers compared to others. Between 2000 and 2007, a slight increase of wheat proportions $(<5 \%)$ is observed: farmers ensure the collection of - most

415 profitable - “wheat” EU aid but maintain enough corn and grassland proportions for dairy production. From 2005 to 2014, a third of farmers retired, leading to farm enlargement. Resumption of dairy quotas and lands favours intensification of existing production. LULCC are consistent with recent trends: proportions of crops increase to the detriment of temporary grassland, and only permanent grassland close to farmsteads remain. Hedgerow removals continue but do not include areas (i) located nearby farmsteads, (ii) beside grassland close to the farmstead, (iii) separating 
fields with two different land uses, and (iv) surrounding riparian wetlands. After the oil crisis of 2008 and 2010, production of biofuels becomes more widespread leading to significant increases of rapeseed (biodiesel), maize, and wheat (bioethanol). Grazing areas are slightly minimized by moving to confined animal feeding operation dairy production. In 2014, EU aids defined in the 2006 CAP reform are not fundamentally challenged and are extended until 2022 thanks to pressure from France. Farmers of Lestolet remain sensitive to environmental concerns and seek to continue preferred practices as long as it is profitable. In 2014 (table 4, Fig. 7a), Lestolet exhibits 392 ha of temporary grasslands, 37 ha of permanent grassland, 307 ha of maize, and 300 ha of wheat. Bocage density detected from aerial photographs is $96 \mathrm{~m} / \mathrm{ha}$ (9km removed, $28 \mathrm{~km}$ undistinguishable from woodlands plots). Riparian wetlands have not shrunk but are more closed with 31ha of permanent grassland, 57 ha of fallow land, and 132 ha of woodland in 2014. Nitrogen concentration is 40-45 mg. $\mathrm{L}^{-1}$ and riparian wetlands enclosure provokes new phenomena of non permanent eutrophication. Theoretical flood hydrograph shows a peak $\left(3.41 \mathrm{~m}^{3} \cdot \mathrm{s}^{-1}\right)$ higher than in $2005\left(3.05 \mathrm{~m}^{3} \cdot \mathrm{s}^{-1}\right)$. In 2015, under pressure of the international community and with rising oil prices, EU allows the use of transgenic crops. Within 2 years, a network of agro-energy industries is being set up to absorb this massively adopted production. Wheat production is maintained to collect EU aid. Grasslands for grazing are limited in order to respect CAP principles for animal welfare. The two consecutive droughts in 2018 and 2019 persuade reluctant farmers to adopt genetically modified crops because they are much less affected. Farm enlargement leads to abandonment of nearly all riparian wetlands, to a rise in maize proportion, and to generalized confined animal feeding operations for dairy production. In 2030 (table 4, Fig. 7b), riparian wetlands are colonized by woodlands, and only permanent grasslands nearby farmsteads remain. Bocage is becoming inconvenient. Hedgerows have been gradually removed since 2015 except those located nearby farmsteads and meadows. Most of the arable lands are converted into crops (436 ha of maize, 356 ha of winter wheat / 445 rapeseed) and remaining grasslands are located nearby farmsteads (204 of temporary and 22 ha of permanent grasslands). Bocage density is $64 \mathrm{~m} / \mathrm{ha}: 27 \mathrm{~km}$ of hedgerows removed and $55 \mathrm{~km}$ 
undistinguishable from woodlands since 2015. Riparian wetlands exhibit 22 ha of permanent grassland, 8 ha of fallow land, and 190 ha of woodlands. Nitrogen concentration regularly exceeds $60 \mathrm{mg}^{-1} \mathrm{l}^{-1}$ and phosphorus concentration causes frequent eutrophication. The theoretical flood

450 hydrograph shows a higher peak $\left(4.01 \mathrm{~m}^{3} \cdot \mathrm{s}^{-1}\right)$ than in 2015.

\#Table 4 approximately here\#

\#Figure 7 approximately here\#

\section{Discussion \& conclusion}

\subsection{Subtle land use and land cover changes: location / frequency versus quantity?}

455 The FLS framework has been used to enhance subtle LULCC and their possible environmental impacts. In the case of the US site, we coupled a forecasting scenario and a spatially explicit and dynamic landscape model. The aim was to assess potential impacts of future LULCC based on trend scenarios, one integrating the end of the Conservation Reserve Program. Results show that a slight increase of crop proportions (e.g. $+5 \%$ of soybean), which may appear quantitatively insignificant,

460 has indirect consequences on other crops in terms of quantity, location, and frequency. Moreover, cumulated with unimportant land conversion to cropland (2.5\%), trend scenarios involve approximately $+3 \%$ of corn proportions with noticeable changes in terms of location and occurrences over the study time period. In this case, benefits of FLS come first from the model’s ability to compute uncertainties of LULCC and second from the long term approach that allows

465 distinguishing LULCC trends from those inherited from stochastic crop successions. In the French case, we coupled a backcasting scenario and a multi-criteria GIS-based approach. The aim was to draw the worst possible future induced by agriculture intensification to evaluate its influence on water quality and fluxes, and to determine key triggers that lead to this undesirable situation. Results show that such a scenario can involve $+2.5 \%$ of maize per year and $-1.4 \mathrm{~m} / \mathrm{ha} / \mathrm{year}$ of 470 hedgerow density between 2000 and 2015, and $+2.8 \%$ of maize per year and $-2.2 \mathrm{~m} / \mathrm{ha} /$ year between 2015 and 2030. Related to the US results, such LULCC are not to be only viewed in terms of quantity but also in terms of location and probable occurrences. Finally, it appears that agriculture 
intensification is not automatically synonymous with conspicuous environmental damages (e.g. US scenarios). It strongly depends on local landscape configuration and farm mosaics, which highlight 475 the relevance of such fine scale FLS.

\subsection{Discussion on the proposed FLS framework}

The reproducibility of the proposed framework has been tested and validated through the elaboration of fine scale FLS on two study sites that exhibit differences in size (factor 10), type of landscapes and agriculture, the use of forecasting/backcasting scenarios, and different landscape modelling techniques. This framework is neither scenario nor model dependent, and particularly adapted to fine scale FLS based on representativeness study sites (step 1 - Fig. 1). Dealing with high spatial and temporal resolution data, the framework contributes to identify the quantity, direction and magnitude of LULCC at fine scales (step 2 - Fig. 1). Identified LULCC are essential in participatory meetings to recognize driving forces and identify stakes to be enhanced through future studies. The scenario building approach (step 3 - Fig. 1) depends on the stakes that are involved. Whatever the forecasting or backcasting building approach chosen, scenarios which are created first must provide all the required information to run the models. The choice of model depends on the type of landscape, the land uses, and land cover change processes. Thus, cellular automata or ABM can be used if they are appropriate. Integration of feedback effects mostly depends on model ability.

490 The resulting maps constitute essential inputs for environmental models or indices to assess possible future impacts of LULCC (step 4 - Fig. 1). This framework contributes to better integrate local specificities (context, land uses and land cover change processes, driving forces) in future LULCC scenario-based studies and quantitatively assess impacts of future landscape changes, but strongly depends on data availability (e.g. farmland maps). For example, it should permit to avoid the use of model (in step 3) that would not be appropriate to model previously identified in step 2 specific LULCC. Its genericity based on the described four steps does not limit its application to subtle LULC changes. It should theoretically be adapted for fine scale FLS dealing with land conversion (deforestation, urban sprawl, etc). We also feel that this framework can contribute to 
downscale regional/national future landscape studies. We encourage investigating this issues.

500 Finally, this framework is somewhat not so different from the 'Story-and-Simulation' approach introduced by Alcamo (2001) and founds its methodological basement from futures and landscape studies.

\subsection{Future improvements for landscape modelling}

The main emphasis of this research was to couple a generic method of future studies (Godet 1986) and landscape dynamics modelling and analysis techniques to propose a framework to foresee fine scale landscape possible futures. These techniques are dedicated (i) to render spatially explicitly landscape dynamics and (ii) to assess environmental impacts of landscape changes with spatial indicators and/or spatially explicit models. The framework genericity comes from various methods and techniques that can be used in step two and three (Fig. 1) which could be largely improved according to the challenges of current LULCC modelling. One of these challenges is to simulate fine scale LULCC. The L1 platform (Gaucherel et al. 2006) has been chosen for its ability to model land use processes in the US study site. However, L1 could be improved: (ii) by coupling an ABM to model farmers' decisions to avoid empirical decisions modelling. This would allow scenarios to be more plausible and helpful to improve LULCC mid-term prediction. In our case, it is not binding

515 because the aim is to foresee the most contrasted landscape futures; (iii) by integrating interactions with global driving forces. More generally, whatever model is used, it has to be able to simulate land uses as well as landscape feature dynamics. This goal could be achieved by refining landscape pattern rendering of ‘top-down’ / pattern-based models (Sohl et al. 2007), by coupling the ‘topdown’ and ‘bottom-up’ approaches (Castella and Verburg 2007), or by modelling multi-scale interactions of human and natural LULCC driving forces (Verburg et al. 2006a,b). An additional challenge is to improve landscape modelling techniques in order to produce dynamic backcasting scenarios respecting different organisational levels and land use. In the US example, we used a simple synchronic multi-criteria GIS, but optimization models (Seppelt and Voinov 2002) could be investigated as well. This is reinforced by the unbalanced forecasting / backcasting studies ratio 
525 induced by large development of dynamic landscape models. Both fine scale forecasting / backcasting scenario approaches are complementary and could inspire decision makers to look beyond the existing landscape and envision greater possibilities (Santelmann et al. 2004) to challenge prediction of 'location versus quantity of LULCC' (Veldkamp and Lambin 2001).

\section{Acknowledgements}

530 This study was partly founded by the French Ministry of Research through the "Aires Culturelles” grant and by the CAREN (Centre Armoricain de Recherches en ENvironnement). Authors would like to thank all US and French farmers and actors for this co-investigation, J. Douvinet and D. Delahaye for the use of the Ruicells model. We would like to thank reviewers for their very helpful comments and suggestions on earlier draft.

\section{References}

Agarwal C, Green GM, Grove JM, Evans TP and Schweik CM (2002) A review and assessment of land-use change models: dynamics of space, time and human choice. USDA Forest Service, Gen. Tech. Rep. NE-297. Available from http://nrs.fs.fed.us/pubs/gtr/gtr_ne297.pdf (Accessed Feb. 2009)

540 Alcamo J. (2001) Scenarios as tools for international environmental assessments. Experts' corner report Prospects and Scenarios No 5. Copenhagen, European Environment Agency: 31.

Bain D and Roubelat F (1994) Profutures - The birth of the strategic prospective and futures studies international network for applied methodology. Futures 26:345-349

Baudry J and Thenail C (2004) Interaction between farming systems, riparian zones, and landscape

545 patterns: a case study in western France. Landsc Urban Plan 67:121-129

Berg R, Stevens R, Jurgensen B, Williamson G and Wiebesiek A (2002) Tillage and crop rotations for southeast South Dakota. SDSU, Coll. of Agric. \& Biol. Sc. - Plant Science Dept. Available from http://plantsci.sdstate.edu/Farm\%20Reports/Beresford\%202002/SERF0201.pdf (accessed Feb. 2009) 
techniques: Towards a user's guide. Futures 38:723-739

Bousquet F and Le Page C (2004) Multi-agent simulations and ecosystem management: a review. Ecol Model 176:313-332

Burgi M, Hersperger AM and Schneeberger N (2004) Driving forces of landscape change - current and new directions. Landscape Ecol 19:857-868

Butler SJ, Vickery JA and Norris K (2007) Farmland biodiversity and the footprint of agriculture. Science 315:381-384

Castella JC, Kam SP, Quang DD, Verburg P and Hoanh CT (2007) Combining top-down and bottom-up modelling approaches of land use/cover change to support public policies: Application to sustainable management of natural resources in northern Vietnam. Land Use Policy 24:531-545

Castella J. and Verburg P (2007) Combination of process-oriented and pattern-oriented models of land-use change in a mountain area of Vietnam. Ecol Model 202:410-420

de Nijs TCM, de Niet R and Crommentuijn L (2004) Constructing land-use maps of the Netherlands in 2030. J Environ Manag 72:35-42

565 Encyclopedia of Earth (2007) Land-use and land-cover change. Washington DC. Available from http://www.eoearth.org/article/Land-use_and_land-cover_change (accessed Feb. 2009) Franklin JF (1993) Preserving biodiversity - species, ecosystems, or landscapes. Ecol Appl 3:202205

Gaucherel C, Giboire N, Viaud V, Houet T, Baudry J and Burel F (2006) A domain-specific 570 language for patchy landscape modelling: The Brittany agricultural mosaic as a case study. Ecol Model 194:233-243

Geoghegan J, Pritchard L, Ogneva-Himmelberger Y, Roy Chowdhury R, Sanderson S and Turner II BL (1998) Socializing the pixel and pixelizing the social in land-use/cover change. In: Committee on Human Dimension of Global Environmental Change (ed.), Linking Remote Sensing and Social 575 Science, National Research Council, Washington DC. pp 51-69

GLP (2005) Global Land Project Science Plan and Implementation Strategy. IGBP Report No. 
53/IHDP Report No. 19. IGBP Secretariat, Stockholm. Available from

http://www.globallandproject.org/Documents/report_53.pdf (accessed February 2009)

Godet M (1986) Introduction to la prospective: seven key ideas and one scenario method. Futures

18:134-157

Godet M and Roubelat F (1996) Creating the future: The use and misuse of scenarios. Long Range Plan 29:164-171

Gordon LJ, Peterson GD and Bennett EM (2008) Agricultural modifications of hydrological flows create ecological surprises. Trends Ecol Evol 23:211-219

585 Greeuw S, van Asselt M, Grosskurth J, Storms C, Rijkens-Klomp N, Rothmans D and Rotmas J (2000) Cloudy crystal balls, an assessment of recent European and global scenario studies and models. Environmental issues series, 17, European Environment Agency, Luxembourg. Hobbs R (1997) Future landscapes and the future of landscape ecology. Lands Urban Plan 37:1-9 Houet T and Gaucherel C (2007) Simulation dynamique et spatialement explicite d'un paysage agricole bocager: validation sur un petit bassin versant breton sur la période 1981-1998. Rev Int Geomatique 17:489-516

Houet T, Hubert-Moy L and Tissot C (2008) Modélisation prospective spatialisée à l'échelle locale: approche méthodologique. Rev Int Geomatique 18:345-373

Houet T and Hubert-Moy L (2006) Modelling and projecting land-use and land-cover changes with

595 a Cellular Automaton in considering landscape trajectories: An improvement for simulation of plausible future states. EARSeL eProceedings 5:63-76

Houghton RA, Hackler JL and Lawrence KT (1999) The US carbon budget: Contributions from land-use change. Science 285:574-578

IPCC (2000) Special report on emissions scenarios, Cambridge, p 27

600 Kahn H and Wiener A (1967) The Year 2000, New York

Kok K, Verburg P and Veldkamp T (2007) Integrated Assessment of the land system: The future of land use. Land Use Policy 24:517-520 
Kristensen SP, Thenail C and Kristensen L (2001) Farmers' involvement in landscape activities: An analysis of the relationship between farm location, farm characteristics and landscape changes in

605 two study areas in Jutland, Denmark. J Environ Manag 61:301-318

Lambin EF, Baulies X, Bockstael N, Fischer G, Krug T, Leemans R, Moran EF, Rindfuss RR, Sato Y, Skole D, Turner BL and Vogel C (1999) Land-use and land-cover change (LUCC):

Implementation strategy, IGBP, Stockholm/Bonn

Lambin EF, Turner BL, Geist HJ, Agbola SB, Angelsen A, Bruce JW, Coomes OT, Dirzo R,

610 Fischer G, Folke C, George PS, Homewood K, Imbernon J, Leemans R, Li XB, Moran EF,

Mortimore M, Ramakrishnan PS, Richards JF, Skanes H, Steffen W, Stone GD, Svedin U, Veldkamp T, Vogel C and Xu JC (2001) The causes of land-use and land-cover change: moving beyond the myths. Global Environ Change Hum Policy Dim 11:261-269

Lambin E and Geist H (Eds) (2006) Land-Use and Land-Cover Change: Local processes and Global

615 Impacts. The IGBP Series, Springer-Verlag, Berlin

Langlois P and Delahaye D (2002) RuiCells, automate cellulaire pour la simulation du ruissellement de surface. Rev Int Geomatique 12:461-487

Loveland TR, Sohl TL, Stehman SV, Gallant AL, Sayler KL and Napton DE (2002) A strategy for estimating the rates of recent United States land-cover changes. Photogramm Eng Remote Sens

68:1091-1099

Marien M (2002) Futures studies in the 21st Century: a reality-based view. Futures 34:261-281

Maron M and Fitzsimons JA (2007) Agricultural intensification and loss of matrix habitat over 23

years in the West Wimmera, south-eastern Australia. Biol Conserv 135:587-593

Matson PA, Parton WJ, Power AG and Swift MJ (1997) Agricultural intensification and ecosystem

625 properties. Science 277:504-509

Maxwell T and Costanza R (1997) An open geographic modelling environment. Simulation 68:175185

Millenium Ecosystems Assessment (2003) Ecosystems and human, Washington. 
Medley KE, Okey BW, Barrett GW, Lucas MF and Renwick WH (1995) Landscape change with agricultural intensification in a rural watershed, South-western Ohio, USA. Landscape Ecol 10:161176

Mérot P (1999) The influence of hedgerow systems on the hydrology of agricultural catchments in a temperate climate. Agronomie 19:655-669

Mérot P, Hubert-Moy L, Gascuel-Odoux C, Clément B, Durand P, Baudry J, Thenail C, (2006) A

Method for improving the management of controversial wetland. Environ Manag 37(2):258-270

Munier B, Birr-Pedersen K and Schou JS (2004) Combined ecological and economic modelling in agricultural land use scenarios. Ecol Model 174:5-18

Nassauer JI and Corry RC (2004) Using normative scenarios in landscape ecology. Landscape Ecol 19:343-356

640 Omernik J (1987) Ecoregions of the conterminous United-States. Ann Ass Americ Geogr 77:118125

Overmars K, Verburg P and Veldkamp T (2007) Comparison of a deductive and an inductive approach to specify land suitability in a spatially explicit land use model. Land Use Policy 24:584599.

645 Paegelow M and Olmedo MTC (2005) Possibilities and limits of prospective GIS land cover modelling - a compared case study: Garrotxes (France) and Alta Alpujarra Granadina (Spain). Int J Geogr Inf Sci 19:697-722

Parker DC, Manson SM, Janssen MA, Hoffmann MJ and Deadman P (2003) Multi-agent systems for the simulation of land-use and land-cover change: A review. Ann Ass Americ Geogr 93:314$650 \quad 337$

Roubelat F (2006) Scenarios to challenge strategic paradigms: Lessons from 2025. Futures 38:519527

Sala OE, Chapin FS, Armesto JJ, Berlow E, Bloomfield J, Dirzo R, Huber-Sanwald E, Huenneke LF, Jackson RB, Kinzig A, Leemans R, Lodge DM, Mooney HA, Oesterheld M, Poff NL, Sykes 
MT, Walker BH, Walker M and Wall DH (2000) Biodiversity - Global biodiversity scenarios for the year 2100. Science 287:1770-1774

Santelmann MV, White D, Freemark K, Nassauer JI, Eilers JM, Vache KB, Danielson BJ, Corry RC, Clark ME, Polasky S, Cruse RM, Sifneos J, Rustigian H, Coiner C, Wu J and Debinski D (2004) Assessing alternative futures for agriculture in Iowa, USA. Landscape Ecol 19:357-374

Schulp CJE, Nabuurs GJ and Verburg P (2008) Future carbon sequestration in Europe - Effects of land use change. Agric Ecosyst Environ 127:251-264

Seppelt R and Voinov A (2002) Optimization methodology for land use patterns using spatially explicit landscape models. Ecol Model 151:125-142

Sheppard SRJ (2005) Landscape visualisation and climate change: the potential for influencing perceptions and behaviour. Environ Sci Policy 8:637-654

Sohl TL, Sayler KL, Drummond MA and Loveland TR (2007) The FORE-SCE model: a practical approach for projecting land cover change using scenario-based modelling. J Land Use Sci 2:103126

Sullivan P, Hellerstein D, Hansen L, Johansson R, Koenig S, Luboswki R, Mcbride W, Mcgranahan D, Roberts M, Vogel S and Bucholtz S (2004) The Conservation Reserve Program: Economic Implications for Rural America. Agricultural Economic Report No AER-834. Available from http://www.ers.usda.gov/publications/aer834/aer834.pdf (accessed Feb. 2009)

Tress B and Tress G (2003) Scenario visualisation for participatory landscape planning: a study from Denmark. Landsc Urban Plan 64:161-178 USDA (1978) Soil survey of Hanson and Hutchison Counties (SD), Soil service conservation. USDA (1979) Soil survey of Yankton County (SD), Soil service conservation. USDA (2002) Census of Agriculture, Table 8: Farms, Land in farms, Value of land and building and Land Use: 2002 and 1997, pp 262-279 van Notten PWF, Rotmans J, van Asselt MBA and Rothman DS (2003) An updated scenario typology. Futures 35:423-443 
Veldkamp A and Fresco LO (1997) Exploring land use scenarios, an alternative approach based on actual land use. Agric Syst 55:1-17

Veldkamp A, Kok K, De Koning GHJ, Schoorl JM, Sonneveld MPW and Verburg P (2001) Multiscale system approaches in agronomic research at the landscape level. Soil Tillage Res 58:129-140 Veldkamp A and Lambin EF (2001) Predicting land-use change. Agric Ecosyst Environ 85:1-6 Verburg PH, Schot P, Dijst MJ and Veldkamp A (2004) Land use change modelling: current practice and research priorities. GeoJournal 61(4):309-324

Verburg P, Schulp CJE, Witte N and Veldkamp A (2006a) Downscaling of land use change scenarios to assess the dynamics of European landscapes. Agric Ecosyst Environ 114:39-56

690 Verburg P, Veldkamp A and Rounsevell MDA (2006b) Scenario-based studies of future land use in Europe. Agric Ecosyst Environ 114:1-6

Verburg P, Eickhout B and Meijl, H. van (2008) A multi-scale, multi-model approach for analyzing the future dynamics of European land use. Annals of Regional Science 42(1):57-77 Vitousek PM, Mooney HA, Lubchenco J and Melillo JM (1997) Human domination of Earth's ecosystems. Science 277:494-499

Wilson GV, McGregor KC and Boykin D (2008) Residue impacts on runoff and soil erosion for different corn plant populations. Soil \& Tillage Research 99:300-307 


\section{Figure captions}

Figure 1: Framework to forecast fine scale landscape futures based on forecasting or backcasting scenarios (adapted from Godet, 1986)

Figure 2: US and French study sites - (a) US study site -the Menno block- location and the 2000 land cover map (Trends research project, Loveland et al. 2002) - (b) French study site -the Lestoletlocation and the 1998 land cover map.

Figure 3: US study site (a) identified crop successions for inventoried systems of production, (b)

705 Physical Environment Suitability Map -PESM- and (c) land users map used as input in L1 modelling platform to simulate future land use and land cover changes based on forecasting scenarios.

Figure 4: GIS multicriteria rule set of land uses employed to map plausible landscape future states in 2015 and 2030 on the French study site based on backcasting scenario.

710 Figure 5: Evolution of land cover proportions for scenario 1 (dashed line) and scenario 2 (plain line) between 2000 and 2020 on the US study site for one simulation. Uncertainties for respective land cover proportions have been computed from 50 simulations.

Figure 6: Detection of corn occurrences for scenarios 1 and 2: (a) number of corn occurrences for scenario 1; (b) mean values of change detection between scenarios 1 and 2 for 50 simulations (c) 715 surfaces (in ha) of corresponding mean values.

Figure 7: Land cover maps for scenario 3 in (a) 2015 and (b) 2030. 
Figure 1

\begin{tabular}{c} 
Scenario Assessment \\
\hline \\
Environmental \\
assessment \\
Indices / models \\
Stakeholders' \\
assessment \\
Scenarios benefits for \\
stakeholders
\end{tabular}


Figure 2

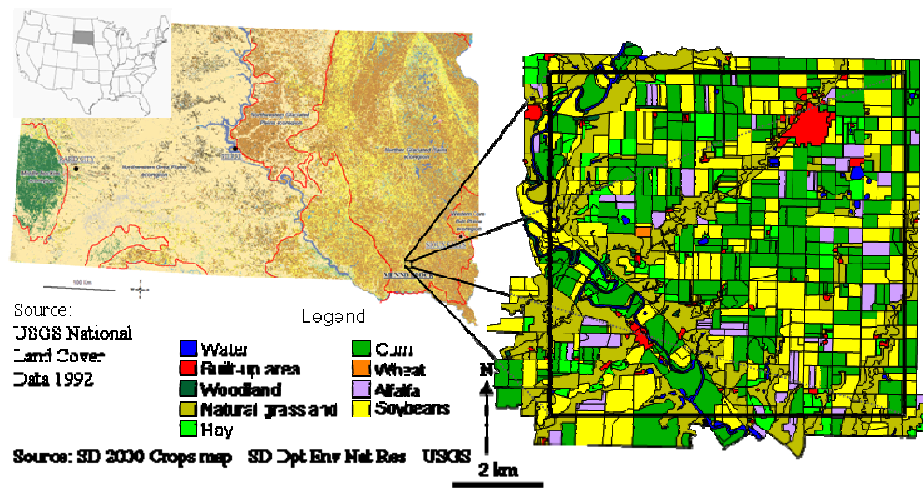

(a)

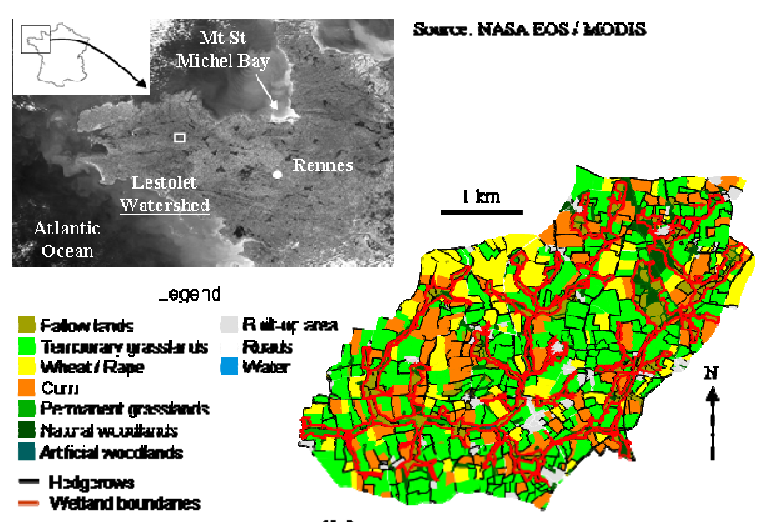

(b) 
Figure 3

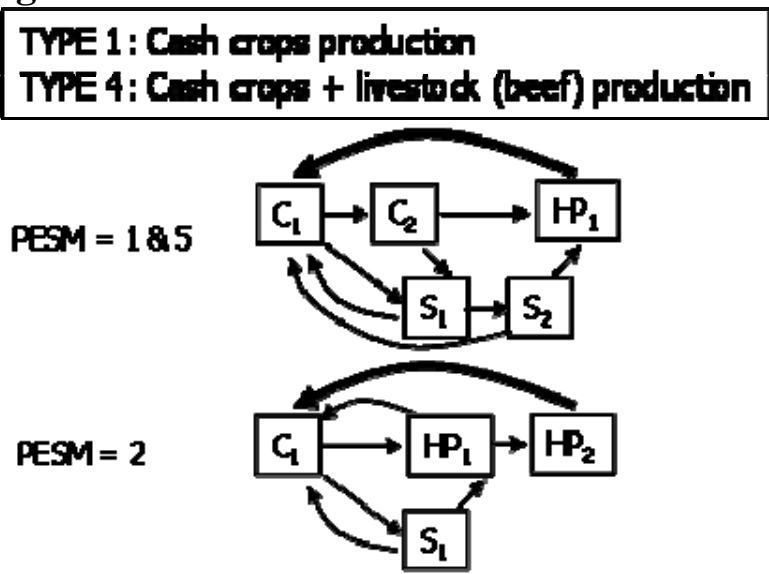

TYPE 2: Cen crops production + lineterek (hegs)

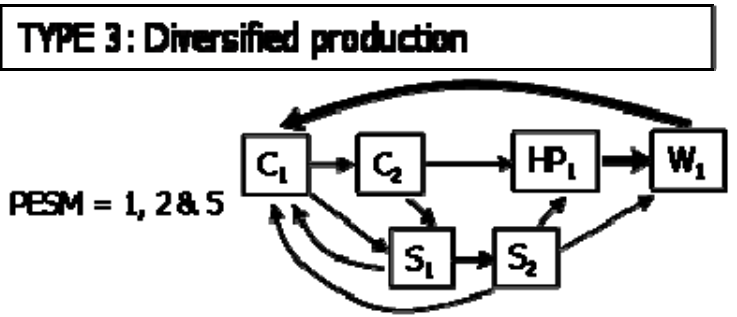

PESM = 185

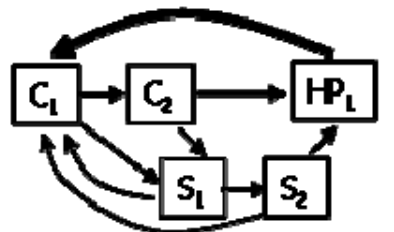

PESM $=2$

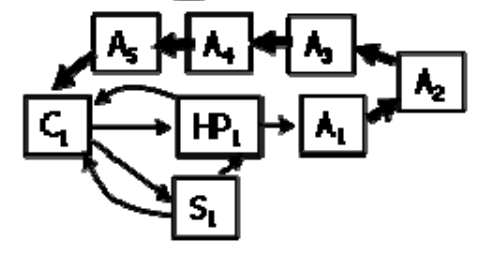

\begin{tabular}{|c|c|}
\hline Lend coner & Lend coura ocalrence/duredon \\
\hline $\begin{array}{l}\text { HP: Happahte } \\
\text { C: Om }\end{array}$ & 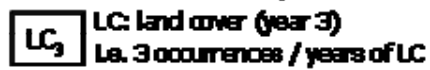 \\
\hline $\begin{array}{l}\text { S Schean } \\
\text { w. What } \\
\text { A: Area }\end{array}$ & 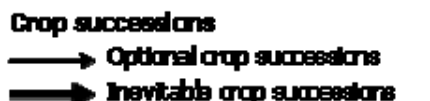 \\
\hline
\end{tabular}

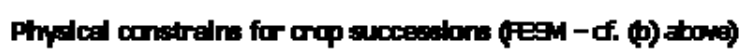

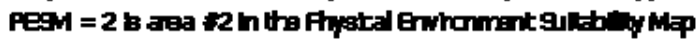

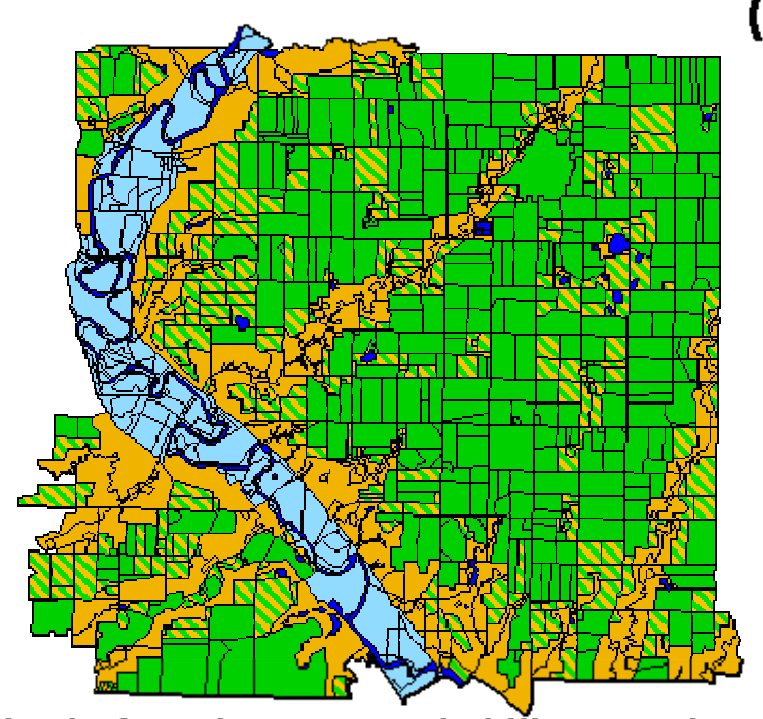

(a)

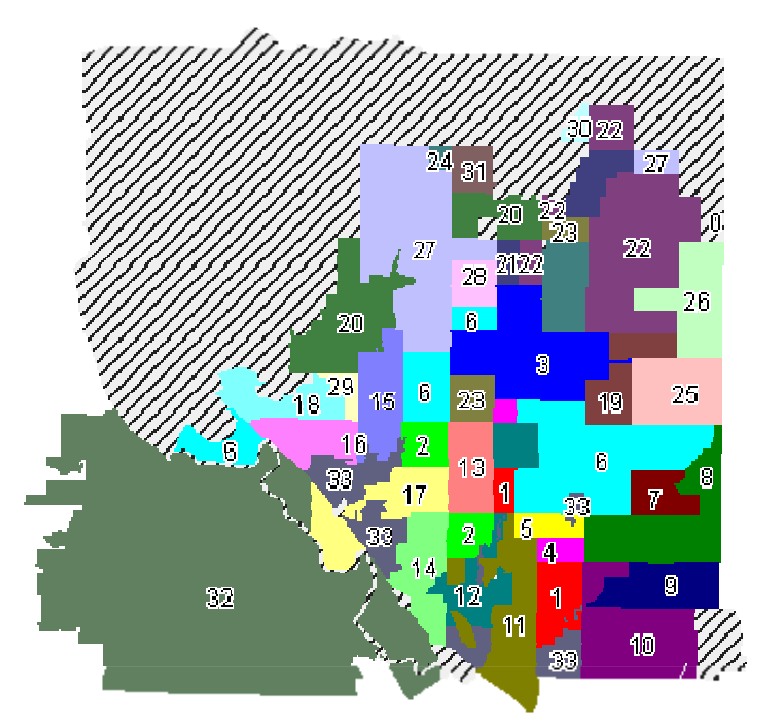

Farm entities IDs

Physical Enviromment Suitability Map (PESM)

$\square$ Potential arable land - no limitation for crops

Potential arable land - limitation for crops

(thin soils, steep slopes)

Potential arable land - limitation for crops

(hazard of flooding, soil moisture)

Non arable land (thin soiks, steep fields)

-historical natural grasslands-

Non arable land (water boclies)

(b)

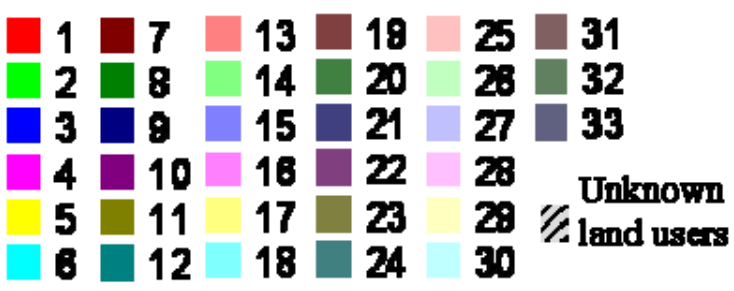

Source: Field survey and local farmers' interviews 


\section{Figure 4}

Location of LUCC $=f$ (farm spatial configuration,

Land cover / hedgerow network distance of fields to farmstead, field size, hydromorphy)

Hedgerow removals $=f($ farm size, system of production, distance of fields to farmstead, neighboring land cover)

Riparian wetlands abandonment = $f$ (farm size, system of production, distance of fields to farmstead, field size)

Type of land cover $=f$ (hydromorphy)

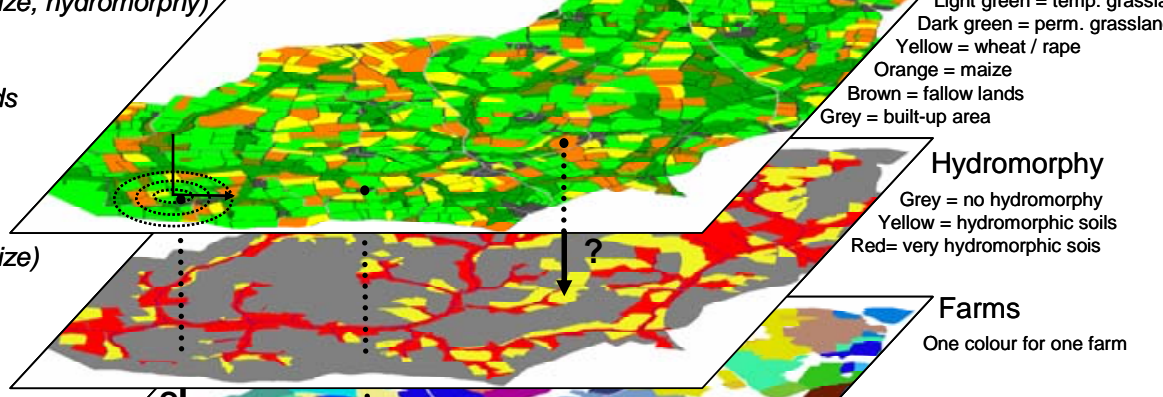

Land cover (ha) $=f($ farm size $)$

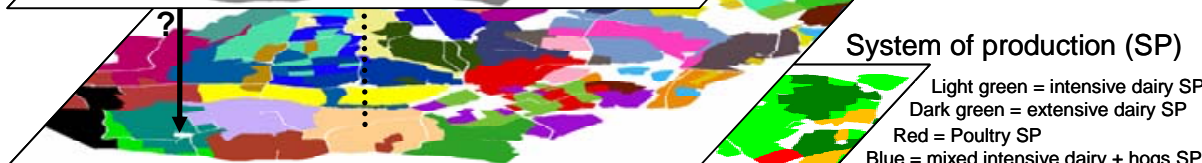

Land cover $(\%)=f($ system of production)

Hedgerow density $=f($ watershed $)$

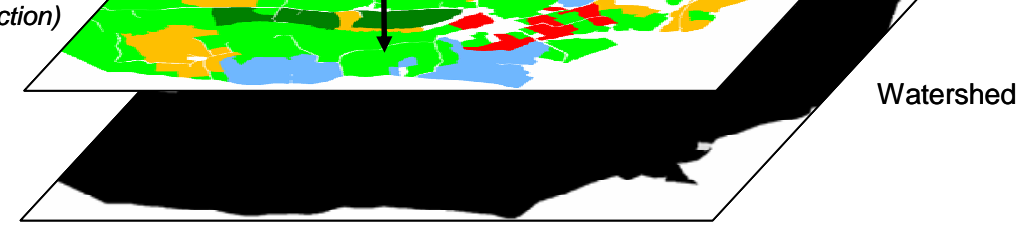




\section{Figure 5}

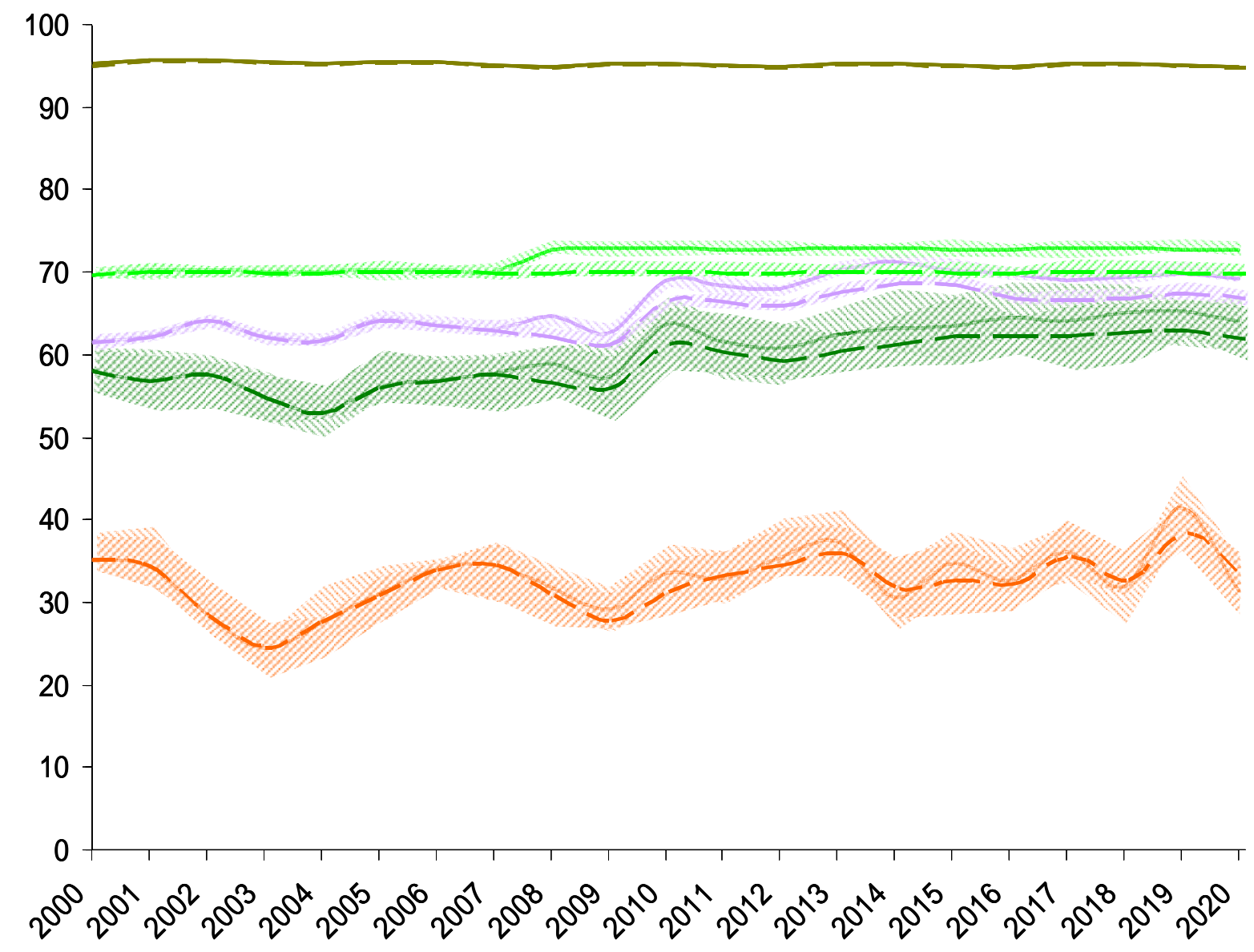

Scenario 1

Scenario 2

Land cover (\%) and associated uncertainty Land cover (\%) and associated uncertainty

- - Fallow land

- - Hay / Pasture

- - Alfalfa

- - Soybean

- - Corn

Hay / Pasture
Alfalfa
Soybean
Corn

- Fallow land

- Hay / Pasture

- Alfalfa

- Soybean

- Corn
$\$$ Hay / Pasture

Alfalfa

Soybean 


\section{Figure 6}

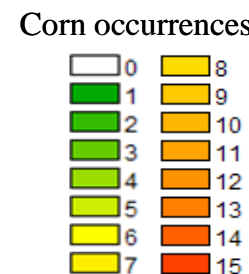

Non arable land

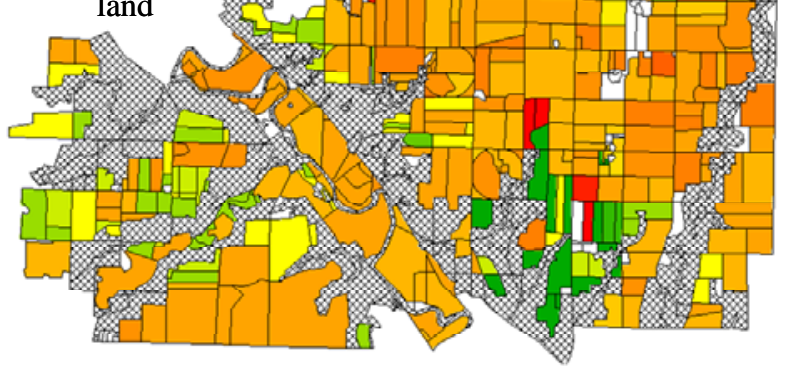

(a)

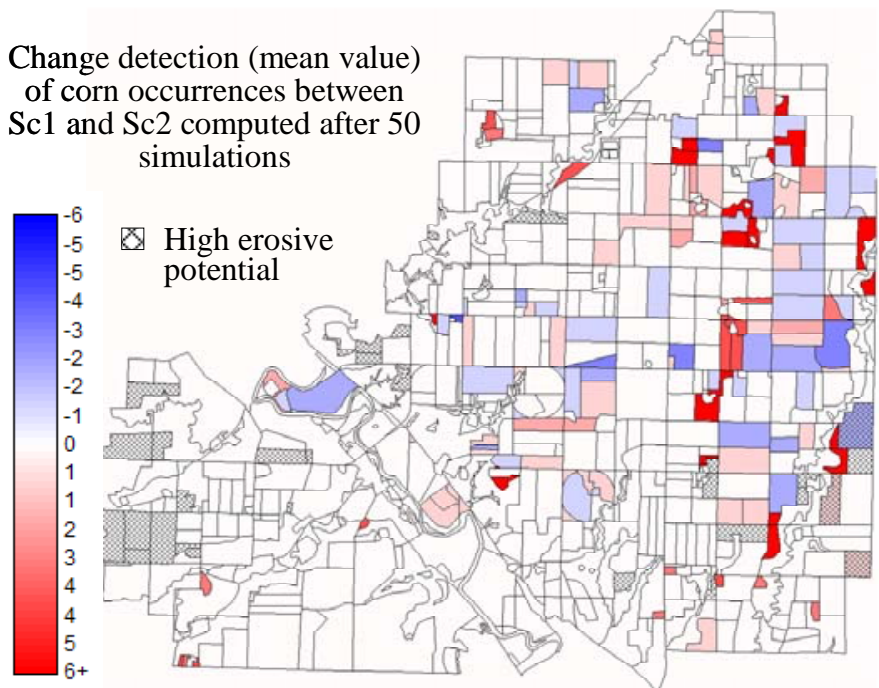

(b)

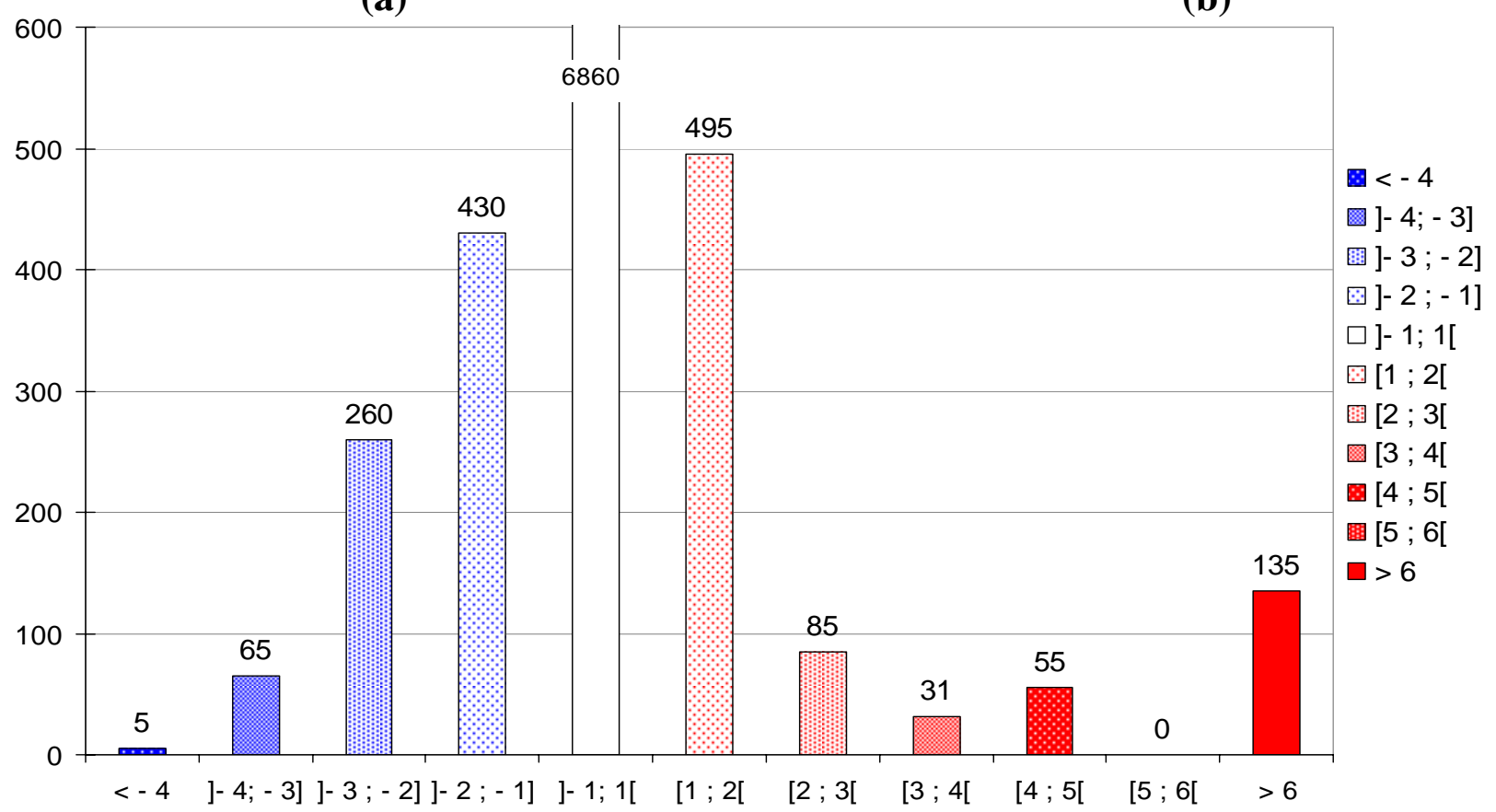

Surface (in ha) by classes of corn occurrences change detection

(c) 
Figure 7

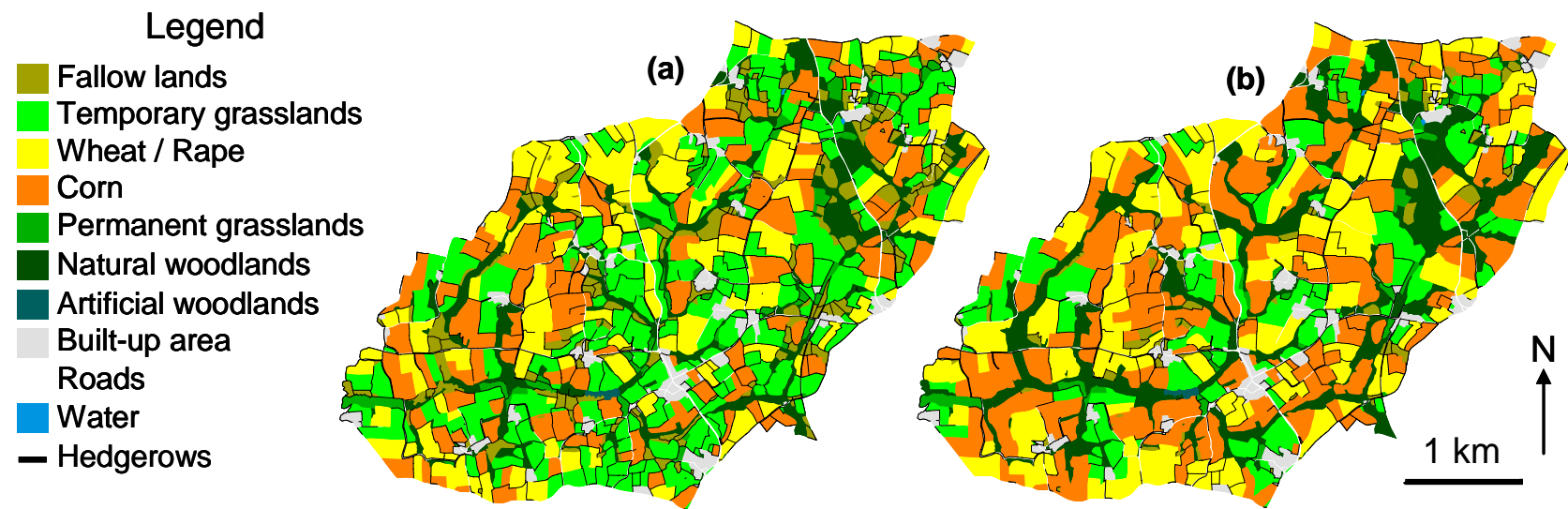


Table 1: Synthesis of the three agricultural intensification scenarios elaborated with the fine scale FLS framework and associated techniques/approaches.

\begin{tabular}{|c|c|c|c|}
\hline & SCENARIO 1 & SCENARIO 2 & SCENARIO 3 \\
\hline Study site & \multicolumn{2}{|c|}{ Menno block (USA) } & Lestolet (France) \\
\hline $\begin{array}{c}\text { Agricultural intensification } \\
\text { assumptions }\end{array}$ & $\begin{array}{c}\text { Trend } \\
\text { (+5\% soybean) }\end{array}$ & $\begin{array}{c}\text { Trend } \\
(+5 \% \text { soybean })+ \\
\text { End of Conservation } \\
\text { Reserve Program }\end{array}$ & $\begin{array}{l}\text { Crop maximization } \\
\text { Wetland abandonment } \\
\text { Massive hedgerow } \\
\text { removals }\end{array}$ \\
\hline Environmental stake & & sion & Water management \\
\hline Scenario building approach & & sting & Backcasting \\
\hline Scenario rendering & Narrati & simulation & Narrative \\
\hline Landscape modelling technique & Dynamic and spa & explicit model (L1) & $\begin{array}{c}\text { GIS / multicriteria } \\
\text { queries }\end{array}$ \\
\hline Landscape changes & $\begin{array}{r}\text { Lanc } \\
\text { Statistics (bas }\end{array}$ & $\begin{array}{l}\text { maps } \\
50 \text { simulations) }\end{array}$ & $\begin{array}{l}\text { Land cover maps } \\
\text { Expert knowledge }\end{array}$ \\
\hline $\begin{array}{l}\text { Environmental assessment } \\
\text { techniques }\end{array}$ & Maps of & occurrences & $\begin{array}{l}\text { Spatially explicit } \\
\text { water flow model } \\
\text { (Ruicell) } \\
\text { Expert knowledge }\end{array}$ \\
\hline
\end{tabular}


5 Table 2: Systems of production and corresponding mean annual crops proportions (US site)

\begin{tabular}{l|c|c|c|c|c|c|} 
& \multicolumn{5}{|c|}{ ANNUAL MEAN CROP PROPORTIONS (\%) } \\
INVENTORIED SYSTEMS OF PRODUCTION & Corn & Soybean & Alfalfa & Hay & Wheat & Nat. grassland \\
\hline Type 1: Cash crops production & 55 & 40 & - & 5 & - & \\
\hline Type 2: Cash crops + livestock (hog) & 50 & 40 & \multicolumn{2}{|c|}{10} & - & \\
\hline Type 3: Diversified production & 50 & 40 & - & \multicolumn{2}{|c|}{10} & \\
\hline Type 4: Cash crops + livestock (beef) & 50 & 40 & - & 10 & - & \\
\hline Type 5: Livestock (beef) production & - & - & - & - & - & 100 \\
\hline
\end{tabular}


Table 3: Evolution of land cover proportions over the studied time frame periods

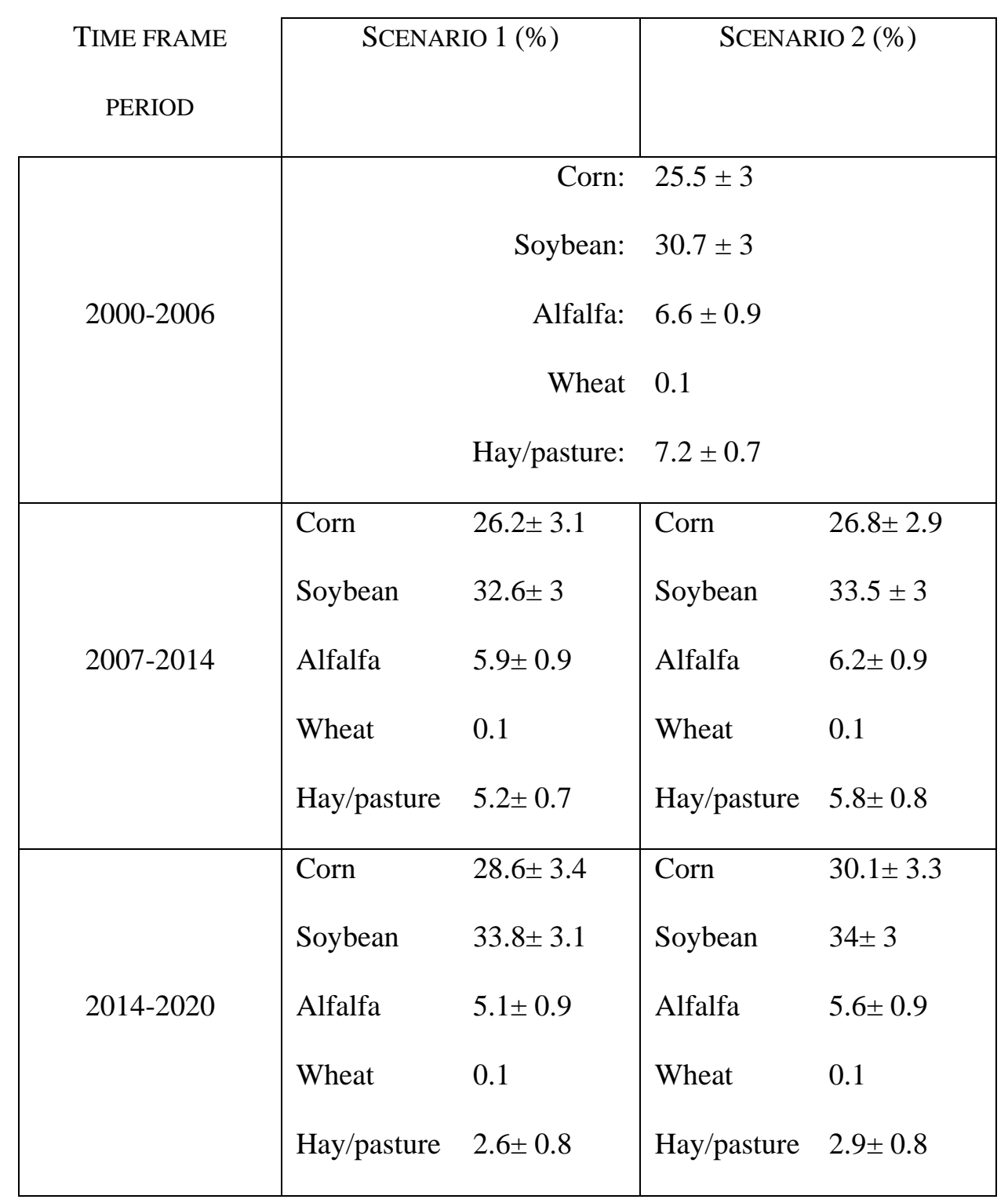


Table 4: Synthesis of landscape dynamics and environmental assessment based on scenario 3 (French site)

\begin{tabular}{|c|c|c|c|c|c|c|c|c|c|c|c|}
\hline \multirow{2}{*}{$\begin{array}{l}\text { SCENARIO } \\
\text { (SC3) }\end{array}$} & \multicolumn{6}{|c|}{ LAND COVER SURFACES (HA) } & \multirow{2}{*}{$\begin{array}{c}\text { EUTROPHICATION } \\
\text { PHENOMENA }^{1}\end{array}$} & RIPARIAN & \multirow{2}{*}{$\begin{array}{l}\text { HEDGEROW } \\
\text { DENSITY } \\
(\mathrm{M} / \mathrm{HA})^{3}\end{array}$} & \multirow{2}{*}{$\begin{array}{c}\text { NITROGEN } \\
\text { CONCENTRATION }^{1} \\
\left(\mathrm{MG.L}^{-1}\right)\end{array}$} & \multirow{2}{*}{$\begin{array}{c}\text { THEORETICAL } \\
\text { WATER PEAK FLOW } \\
\left(\mathrm{M}^{3} . \mathrm{S}^{-1}\right)\end{array}$} \\
\hline & TG & $\mathrm{M}$ & Wh & PG & FL & Wd & & ENCLOSURE $^{2}(\%)$ & & & \\
\hline 1981 & 711 & 211 & 159 & 135 & 57 & 28 & None & 38 & 146 & ? & $?$ \\
\hline $2000^{5}$ & 578 & 224 & 200 & 40 & 123 & 57 & None & 81 & 123 & 35 & 3.05 \\
\hline 2015 & 392 & 307 & 300 & 37 & 57 & 132 & Irregular & 87 & 96 & $40-45$ & 3.41 \\
\hline 2030 & 204 & 436 & 356 & 22 & 8 & 190 & Frequent & 90 & 64 & $>60$ & 4.01 \\
\hline
\end{tabular}

? = unknown values

TG: Temporary Grassland, M: Maize, Wh: Wheat,

15 PG: Permanent Grassland, FL: Fallow Land, Wd: woodland

${ }^{1}$ Estimated from literature and expert knowledge

${ }^{2}$ Proportion of riparian wetlands covered by fallow and wood that lead to landscape enclosure estimated from derived from land cover maps

${ }^{3}$ Hedgerow density computed from aerial photographs and estimated so that undistinguishable hedgerows surrounding woodland plots are not accounted

${ }^{4}$ Theoritical water peak flow computed from coupling land cover maps and the spatially explicit model Ruicells (Langlois and Delahaye 2002)

$20 \quad{ }^{5}$ Situation in 2000 is assimilated to situation in 1998 
Appendix 1: Remotely sensed data used for trends / land use identification on US and French study sites

\begin{tabular}{|c|c|c|}
\hline & US study site & French study site \\
\hline $\begin{array}{l}\text { Remotely } \\
\text { sensed data }\end{array}$ & $\begin{array}{l}\text { USDA-FSA-APFO Digital Ortho Mosaic } \\
\text { 04/22/1998, 08/02/2003, 08/08/2004 } \\
\text { Landsat MSS - 08/28/1973 } \\
\text { Landsat TM - 08/29/1984, 08/17/1991, } \\
\text { 08/09/1993 } \\
\text { Landsat ETM+ - 06/30/2000, 10/20/2000 }\end{array}$ & $\begin{array}{l}\text { IGN Aerial photographs - 05/23/1952, } \\
\text { 05/16/1966, 08/18/1981, } \\
\text { IGN Digital ortho mosaic 08/08/1998 } \\
\text { SPOT } 2 \text { HRV - 12/29/1996, 01/24/2001, } \\
\text { 08/15/1997 } \\
\text { IRS-LISS 1D - 03/16/1999 } \\
\text { IRS-LISS 1C - 12/13/1997, 03/08/2000 } \\
\text { SPOT } 4 \text { HRVIR - 12/17/2001 } \\
\text { SPOT } 5 \text { HRVIR - 09/13/2002 }\end{array}$ \\
\hline
\end{tabular}

